\title{
Housing Prices in a Market Under Years of Constant Transformation: A County-Based Analysis of Istanbul
}

\author{
Meltem Ucal, Uğur Kaplan
}

A B S T R A C T

Objective: The objective of the article is to present a comprehensive approach to analysing Istanbul's housing prices, using a hedonic price model with a large dataset and a single variable for locational attributes.

Research Design \& Methods: The analysis of consequent housing prices in İstanbul's counties with hedonic price modelling and the extrapolation of results by comparing the prices to the human development level of counties. We use multiple regression and Ordinary Least Squares (OLS) methods to estimate two semi-log hedonic price models for two time periods.

Findings: The relationship between socioeconomic development levels and housing prices varies for counties under different urban transformation processes.

Implications \& Recommendations: The results are useful for the housing price analysis in Istanbul. The housing prices appear to follow the socioeconomic development level of the county in which a house is located, thus showing variations between different counties. The relationship between housing prices and urban transformation processes should be approached with caution by policymakers, as the outcomes may disturb both the sociological and economic balance in the long run.

Contribution \& Value Added: The study contributes to the existing research on housing price analysis by interpreting locational attributes as a whole and housing research at large by combining hedonic price modelling and case study methods.

\begin{tabular}{ll}
\hline Article type: & research article \\
Keywords: & housing prices; semi-log hedonic price model; Istanbul
\end{tabular}
JEL codes: Q1, Q18, C25

Received: 20 September $2019 \quad$ Revised: 5 March $2020 \quad$ Accepted: 30 March 2020

\section{Suggested citation:}

Ucal, M., \& Kaplan, U. (2020). Housing Prices in a Market under Years of Constant Transformation: A County-Based Analysis of İstanbul. Entrepreneurial Business and Economics Review, 8(2), 71-91. https://doi.org/10.15678/EBER.2020.080204 


\section{INTRODUCTION}

The housing prices change dramatically within an urban area when there is an ongoing urban transformation process such as urbanisation, urban regeneration, gentrification or suburbanisation (Guerrieri, Hartley, \& Hurst, 2013). These kinds of urban transformation simultaneously shape the entire area socioeconomically and demographically (Atkinson \& Bridge, 2005; Steinmetz-Wood et al., 2017). Istanbul - one of the most densely populated cities in the world - has recently witnessed a substantial acceleration in urban transformation. The suburbanisation, urban development, and modernisation of its buildings has been intense for over a decade, catalysed by many policy changes (The World Bank, 2015).

This article analyses consequent housing prices and their relationship with human development levels in Istanbul's counties. The analysis method is a combination of quantitative and qualitative methods. The study estimates prices by hedonic price modelling and extrapolates findings by juxtaposing the prices to the human development level of counties in the quantitative part. Then, we interpret extreme cases of price and human development discrepancies on the basis of case studies of three types of counties and existing research from various sociological fields.

The article is organised as follows: the first section scrutinises the discussed background of housing sector related to the article target, second section is methodology, followed by a discussion of results, and the last section is conclusion.

\section{LITERATURE REVIEW}

One of the components of a house that influences its price the most is location (Bradbury et al., 1977; Ottensmann, Payton, \& Man, 2008). This is mainly due to some aspects of the daily life being shaped by either the exact location or the neighbourhood to which the house belongs (Li \& Brown, 1980). Consequently, it is not uncommon for people to determine a certain set of target neighbourhoods when searching for a house to purchase. For example, prospective buyers tend to highly rate the neighbourhoods that offer a short commuting time to work (Lipscomb, 2006; Xiao, 2017). Likewise, houses are often priced higher when there are high quality schools and various amenities in the proximity (Dokmeci et al., 1996). It is evident that car ownership alters the preferability of locational attributes of houses, thus the significance of price (Ciraci \& Kundak, 2000; Frenkel, Bendit, \& Kaplan, 2013). Additionally, the locational attributes vary largely within the metropolitan area, making their effect on price all the more inconsistent. Evidence from previous research indicate that the relationship between housing prices and locational attributes is worthy of further inquisitive effort (Głuszak, 2018).

The discussion presented so far raises the question if and how large a correlation exists between housing prices and the locational attributes in large cities. In this context, Istanbul is a legitimate city to examine, with a large urbanised metropolitan area and high variability in housing prices. The locational attributes of Istanbul's 39 counties are aggregated into and ranked by two indices, namely the "Life Quality Index" (Şeker, 2015) and the "Human Development Index" (Şeker, Bakış, \& Dizeci, 2018). A ranking among counties may as well be performed by using housing prices. This article hypothesises that - when ranked - the housing prices in Istanbul's counties would show a significant correlation with their index rankings. 
Istanbul has seen constant a growth of population through migration for the last 50 years (Keskin, 2008). As with other metropolitan cities, the transformation of urban areas is needed as much as their expansion. Istanbul shares the same urban transformation policy as Turkey, criticised for its poor planning (Gülersoy \& Güler, 2011; Karaman, 2009), revenue-generation-oriented (Efe et al., 2015; Kisar Koramaz, Koramaz, \& Özer, 2018; Özdemir Sarı, Özdemir, \& Uzun, 2019), and its inability - or, in some cases, disregard - to preserve cultural values and social capital (Ozden, 2012).

The general urban transformation scheme in Turkey is a combination of urban renewal, suburbanisation, and urban redevelopment. In the case of Istanbul, it has three major lanes: (1) the urban renewal of old houses susceptible to earthquakes in old neighbourhoods; (2) the area-based regeneration of neighbourhoods labelled risky based on the Law on Transformation of Areas under Disaster Risk enacted in 2012, regarded as a veiled effort of slum clearance; and (3) suburbanisation through new housing projects on public lands, executed by private companies (Turkmen, 2014; Yılmaz Bakır, 2019).

Because Istanbul is one of the oldest cities in the world, some of its most central neighbourhoods are historically significant. Therefore, they are less likely to be targeted for a mass renewal. The urban transformation projects undertaken in this kind of counties in recent years are mostly renovations and individual renewal of old houses (Kisar Koramaz, Koramaz, \& Özer, 2018). Like in any metropolitan area, social amenities are abundant and human development level is higher in inner city Istanbul. Consequently, there is some merit in investigating whether the housing prices in Istanbul's central counties are high as well. We expected that there would be little to no discrepancies between the ranking of housing prices and indices in the case of counties with old settlements.

The neighbourhoods that once used to be outer districts of Istanbul - inhabited by poorer demographic - have gradually become inner city (Güler, 2013; Ocakçı, 2000). These areas have recently become the primary sites of urban transformation policies, mainly in the form of gentrification. It is also the case that these areas have more access to amenities and services than the more remote counties (Yapıcı \& Ileri, 2019). Hence, it is very likely that there is a potential revenue generation in gentrifying these areas by the construction of modern housing projects. In most cases, homeowners in a block that consists of risky buildings are collectively offered a deal by the contractor, which requires the consent of all the involved homeowners. In exchange for their houses, the homeowners are offered either an upfront payment or an apartment in a finished project that is to occupy the land emptied by demolished houses (Yılmaz Bakır, 2019).

Lower income households living in the gentrified areas are pushed to outer city neighbourhoods, as they are replaced by a new group of residents with potentially higher income and higher education (NYU Furman Center, 2015). Consequently, one of the most common outcomes of a gentrified area is an improvement in the quality of infrastructure, be it social or physical (Michalos, 2014). This is related to the demographic change, since new residents are likely to be professionals who opt to live in smaller households with fewer children, if any. In the social context, this shift causes the average size of houses to decrease. In the economic sense, this change of construction increases prices per area and the total area of living. Therefore, gentrification eventually causes an increase in rents, property values, and taxes within and around the gentrified area (Martin \& Beck, 2018). This discussion indicates that gentrification is not only related to demographic changes. 
However, it is expected to impact many more aspects of life quality in such neighbourhoods or even the whole city (Steinmetz-Wood et al., 2017).

Noteworthy, individuals across the board prefer to live in richer neighbourhoods compared to poorer neighbourhoods, with the expectancy of better access to public goods and services and the convenience of amenities (Michalos, 2014). However, the above process proposes an interesting aspect of gentrification that the economic changes might as well trigger demographic and social changes in gentrified areas (Billingham, 2015; Zambon \& Salvati, 2019). A recent example are the urban renewal projects in squats of Ankara, which involve giving homeowners a house from the new projects. However, low-income households, unable to cope with the eventual increase in maintenance costs that come with the improvement of amenities and services, ended up selling their houses for a subjectively large sum of money (Atkinson \& Bridge, 2005). Therefore, the impact and intent of gentrification might be observed to have a great variation from displacement and marginalisation of certain social groups to quality of life improvements (The World Bank, 2015; Wacquant, 2008). This has been confirmed in a qualitative study in Istanbul, where residents of an old industrial area reported they appreciate the developments related to the introduction of gated communities (Güler, 2013). In light of the above, the counties with gentrified areas in Istanbul are expected to rank higher in prices than indices.

Suburbanisation is defined as the spatial reorganisation of a city in consequence of growing population. Low-density areas attract amenities as their population grows, and there arise suburbs that have their own organisation. The suburbs gained popularity thanks to lower costs of car ownership and the increasing income levels, although they still rely on commuting (Michalos, 2014). In Istanbul, large areas that allow for the construction of gated communities with shopping malls have become much more common with the urbanisation policies of administrative bodies. Public lands are offered to private construction companies as a partnership deal with governmental agency of public housing, TOKI (Bodur \& Dülgeroğlu Yüksel, 2017). In cities under intense urban transformation, the newly-built housing projects eventually see an overall increase in housing prices when social amenities become extensive (Montgomery, 2008; Tang, 2006). Istanbul's counties with extensive suburban settlements are usually in mid to low ranks in human development indices. In the future, many unsettled areas in various counties of Istanbul are expected to receive better public services, such as road construction or schools. However, the review of literature presented here indicates that suburbanised counties of Istanbul rank higher in socioeconomic development indices than price.

After integrating all the above, we construct our hypotheses as follows:

H1: There is a correlation between housing prices and the socioeconomic development levels of counties.

H2: Older counties have higher housing prices and socioeconomic development.

H3: Suburbanised counties rank higher in socioeconomic development than price.

H4: Counties with gentrified areas rank higher in price than socioeconomic development. 


\section{MATERIAL AND METHODS}

This study investigates the hypotheses through a combination of quantitative and qualitative analysis. Firstly, we apply hedonic price modelling to our dataset of 2235245 observations, in which sales price is the dependent variable and the independent variables of age, size, and county are predictors. Secondly, we use the estimation output to rank counties according to their coefficients. The obtained rankings are used to run a correlation analysis with socioeconomic development rankings of Istanbul's counties. The coefficient and index rankings of certain types of counties are assessed in a case study of specific groups of counties.

There are two indices ranking Istanbul's counties according to socioeconomic development levels: Life Quality Index and Human Development Index. We estimate separate models corresponding to each of the indices by splitting the dataset into two. In our first model, we regress housing prices from January 1, 2015 to December 31, 2016 and interpret the findings via the "Life Quality Index of Istanbul" (LQI; Şeker, 2015). The estimation in our second model follows the same path, using the data from January 1, 2017 to July 15, 2018 and the "Human Development Index of Istanbul" (HDI; Şeker, Bakış, \& Dizeci, 2018). The rankings of Istanbul's counties are taken as references for the coding of county variable in our study. The lowest ranking counties in the indices are determined as the base levels for the county variable in corresponding models, which are Arnavutköy and Şile.

We use a hedonic price model, in which housing price is predicted by structural and locational attributes of a housing unit, used as independent variables. The hedonic approach is widely recognised as superior compared to macroeconomic and repeat sales methods in housing. The macroeconomic perspective views the estimation of housing prices solely as a problem of supply and demand, which is proven only marginally compatible with heterogeneous products. Hill (2011) extensively discusses the issue of method selection and suggests that the repeat-sales method and hybrid methods are incompetent compared to hedonic models. On top of that, the houses in Turkey receive no unique identifiers, which sets a barrier to conducting an analysis with repeat-sales method. There are also hedonic price methods in literature that treat time as a dummy variable, hence the name "Time-Dummy Method" (de Haan \& Diewert, 2013; Hill, 2011). We opted to estimate two separate models for different time periods instead of one model with a time dummy, as our study focuses on the comparison between human development and price, not price changes over time.

The key assumption of the model is that the total effect of locational attributes of a house can be expressed by the county in which it is located. This assumption is based on the premise that the effects of locational attributes are contingent (Heyman \& Sommervoll, 2019). On that account, while theoretically valid, it is not meaningful to measure the marginal effect of unit change in predictors, i.e. a house's distance to the city centre (Fletcher, Gallimore, \& Mangan, 2000). That being stated, using a limited number of predictors poses a risk of omitted variable bias, which is a result of omission of an independent variable that potentially affects the dependent variable. In fact, the number of variables included in a linear regression proposes a trade-off between issues of multicollinearity and omitted variable bias (Hülagü et al., 2016), both of which are incompatible with assumptions of Ordinary Least Squares (OLS). The authors concede the bias and avoid multicollinearity by using few variables. This decision is 
based on four grounds. Firstly, multicollinearity is considered a more important problem in hedonic regression, because it may result in a problem so severe that the predictors produce opposite signs of their actual effect (Xiao, 2017). Secondly, the assumption of the lack of bias can be flexible in certain situations, and it is recommended to opt for a biased estimator, especially if it offers less variance than an unbiased one (Salkind, 2010). Thirdly, omitted variable bias may never get terminated, while remedies like control variable may even increase the bias (Clarke, 2005). Fourthly, since we use the rankings of coefficients to analyse counties rather than the values of coefficients, a potential bias would not be a great concern for this study's results. This bias would affect every coefficient in the same direction (either over- or underestimation) and, thus, would not change the rankings.

The interpretation of marginal effects in a hedonic price model has some practical impairments that stem from the requirement of holding other variables constant when interpreting one's effect (Xiao, 2017). This requirement becomes even more impractical when interpreting marginal effects of categorical variables. For example, holding a variable like sea view constant is not always entirely possible when one interprets the effect of the house's floor. In a practical sense, it is impossible to interpret the marginal price change of switching form a rooftop with a sea view to a basement floor while holding the sea view constant. Similarly, locational attributes are often categorical in a hedonic model and suffer from the same impracticality. The varying levels of socioeconomic development and demographics within the metropolitan area make the effect of locational attributes to fluctuate. For example, the effect of school proximity on price is not constant across the sample. It would be much higher for a house in the suburbs compared to the one in inner city. Therefore, tracking marginal changes would have more explanatory power when locational attributes are treated as a whole. This is not to disqualify the findings in the extensive literature on the hedonic modelling of housing prices. However, it is compelling to incorporate all of the locational attributes in the interpretation at once (Lipscomb, 2006). To achieve this, the study uses county as the factor variable in its modelling. We then rank the prices across counties and run them through a correlation analysis with rankings from LQI and HDI. These indices take into account a wide range of spatial and socioeconomic attributes in counties, such as the education level of residents and the number of hospitals in the county. We used the rankings from indices in the county variable, rather than actual index scores, so as to enable interpretations appropriate to the study's aim.

In order to avoid ambiguities and misclassifications, we limited our dataset to only one particular type of housing unit in this study: apartments. We take the natural logarithm of the dependent variable, as the semi-log level is the typical form proposed in literature (de Haan \& Diewert, 2013; Hill, 2011). We do this mostly to address the heteroscedasticity issue inherent to hedonic models (Xiao, 2017). Despite this transformation of dependent variable, the error terms might still display heteroscedasticity, which is not compatible with OLS assumptions. In this case, estimation with robust standard errors is suggested. The interpretation of coefficients with the logarithm approach is done in proportions, which provides a more sensible explanation of variance in the dependent variable than reporting a fraction of unit change caused by a unit change in independent variables. Our proposed model is as follows:

$$
\ln P=\propto_{0}+\sum_{i=1}^{n} \propto_{i} z_{i}+\varepsilon
$$


in which $\mathrm{P}$ is the transaction price of the property, $\ln P$ is the logarithmic form of $\mathrm{P}, z_{i}$ is a housing characteristic, $\propto_{0}$ is the intercept term, $\propto_{i}$ is the coefficient of a housing characteristic; and $\varepsilon$ is the error term. We use OLS method and STATA 14 software package to estimate models. We identify the logarithm of price as the dependent variable, the age of building and the size of the apartment as continuous explanatory variables, and the county in which the house is located as discrete explanatory variable. The age and size are the most used variables in the housing sector research, consistently proven to have similar effects across studies (Goodman, 1978; Goodman \& Thibodeau, 2003; Hill, 2011; Kangallı Uyar, 2015; Kaya, 2012; Keskin, 2008; Li \& Brown, 1980; Song \& Knaap, 2004).

We then continue to investigate the relationships between the coefficients and the development levels of Istanbul's counties. Our dataset consists of 2235245 real estate sales ads from January 1, 2015 to July 15, 2018, which cover only apartment units. The observation count in our study is higher than most studies, which is likely to lead to significant estimators. The data is obtained from a data and analytics firm REIDIN, which operates in real estate and finance sectors that serves investors, banks, and other interested parties in Turkey.

\section{RESULTS AND DISCUSSION}

\section{Descriptive Statistics}

In Table 1, we present the mean price, age, and size of apartments in counties. We can easily notice in frequencies that the older (hence the more central) the county is, the fewer new properties are listed for sale there, according to the Turkish Statistical Institute's (TURKSTAT) “Building Permits Statistics" data of 2015, 2016, and 2017. Coupled with the mean prices, this observation can be extrapolated, as the prices tend to be higher on average in the older counties of Istanbul.

Mean prices in the old central counties such as Bakırköy, Beşiktaş, Beyoğlu, Kadıköy, and Üsküdar are higher than all other counties, except for Sarıyer and Beykoz. The counties that follow this group - such as Maltepe, Fatih, Zeytinburnu, and Eyüp - are on the periphery of the most central counties. The average age of apartments in those counties is lower in respect to that in the most central counties and they have more than a few gentrified areas. Bahçelievler, Bayrampaşa, Gaziosmanpaşa, Avcılar, Bağcılar, Ümraniye, and Kağıthane have seen a sizeable number of new construction projects. Therefore, their mean age of apartments for sale is relatively low. The mean prices of apartments in the said counties vary between 300000 TL and 430000 TL. Arnavutköy, Sultangazi, Beylikdüzü, Esenyurt, Sancaktepe, and Pendik are counties with a high number of apartments for sale and a high number of new projects.

\section{Regression}

Model 1 is estimated based on observations from January 1, 2015 to January 1, 2017 and Model 2 by observations from January 1, 2017 to July 15, 2018. We first tested both models for robustness against model specification errors by estimating different regressions that test the same hypotheses with an alternating set of predictors. We kept county dummies as the main variable and alternated age and size as test variables. The test variables produced significant coefficients with consistent signs. Results from Table 2 indicate that our primary models are robust to the specification error. Consequently, we proceeded with our main models. 
Table 1. Descriptive Statistics

\begin{tabular}{|c|c|c|c|c|c|c|c|c|}
\hline \multirow{2}{*}{ County } & \multirow{2}{*}{ Frequency } & \multicolumn{2}{|c|}{ Price (TRY) } & \multicolumn{2}{|c|}{ Age } & \multicolumn{2}{|c|}{ Size $\left(m^{2}\right)$} & \multirow{2}{*}{$\begin{array}{c}\text { New } \\
\text { Projects* }\end{array}$} \\
\hline & & mean & st dev & mean & st dev & mean & st dev & \\
\hline Adalar & 4025 & 668534 & 374694 & 27.0 & 8.5 & 122.2 & 55.5 & 9 \\
\hline Arnavutköy & 21631 & 255514 & 102558 & 1.9 & 3.5 & 119.2 & 43.6 & 1931 \\
\hline Ataşehir & 69448 & 623838 & 444787 & 7.9 & 7.3 & 116.6 & 47.4 & 1346 \\
\hline Avcılar & 77732 & 300461 & 148319 & 8.5 & 9.7 & 117.9 & 43.2 & 866 \\
\hline Bağcılar & 44833 & 378604 & 187440 & 6.1 & 8.0 & 115.3 & 38.9 & 1868 \\
\hline Bahçelievler & 130825 & 415142 & 276017 & 10.3 & 11.4 & 115.8 & 42.8 & 1323 \\
\hline Bakırköy & 35048 & 1171173 & 1228914 & 18.1 & 14.4 & 128.8 & 64.4 & 364 \\
\hline Başakşehir & 55568 & 498828 & 336770 & 6.3 & 6.0 & 132.3 & 54.9 & 811 \\
\hline Bayrampaşa & 18492 & 419539 & 211082 & 8.0 & 9.4 & 116.3 & 44.3 & 1046 \\
\hline Beşiktaş & 32094 & 1,130423 & 727180 & 22.9 & 13.0 & 117.3 & 46.3 & 165 \\
\hline Beykoz & 8868 & 770473 & 526306 & 15.7 & 8.7 & 144.5 & 58.4 & 40 \\
\hline Beylikdüzü & 134983 & 300690 & 165051 & 3.4 & 5.4 & 125.2 & 45.9 & 1827 \\
\hline Beyoğlu & 27976 & 606936 & 509011 & 23.4 & 18.5 & 100.7 & 41.5 & 423 \\
\hline Büyükçekmece & 50788 & 446721 & 259591 & 9.7 & 8.9 & 143.5 & 58.7 & 956 \\
\hline Çatalca & 2752 & 314553 & 160594 & 6.3 & 7.5 & 133.2 & 56.2 & 201 \\
\hline Çekmeköy & 48863 & 340160 & 176280 & 3.9 & 4.4 & 111.7 & 40.7 & 1343 \\
\hline Esenler & 28102 & 254700 & 104210 & 5.9 & 7.8 & 93.5 & 20.4 & 1359 \\
\hline Esenyurt & 146595 & 218288 & 107802 & 2.7 & 3.7 & 106.7 & 32.6 & 4778 \\
\hline Eyüp & 85092 & 508042 & 374863 & 4.1 & 5.5 & 118.8 & 47.2 & 1700 \\
\hline Fatih & 43000 & 425494 & 255893 & 27.5 & 11.3 & 97.9 & 36.7 & 557 \\
\hline Gaziosmanpaşa & 52111 & 357012 & 187088 & 7.9 & 8.1 & 116.0 & 41.1 & 786 \\
\hline Güngören & 27781 & 365284 & 204767 & 21.0 & 10.7 & 110.2 & 37.4 & 210 \\
\hline Kadıköy & 168621 & 1210483 & 753112 & 10.1 & 12.9 & 143.6 & 48.9 & 1098 \\
\hline Kağıthane & 71666 & 389242 & 173987 & 3.9 & 6.0 & 102.0 & 37.7 & 1743 \\
\hline Kartal & 93313 & 422801 & 229060 & 7.1 & 8.9 & 117.5 & 39.4 & 984 \\
\hline Küçükçekmece & 95513 & 402235 & 239454 & 6.4 & 7.8 & 112.5 & 44.6 & 2422 \\
\hline Maltepe & 125347 & 503721 & 251593 & 8.1 & 10.2 & 121.4 & 46.1 & 1180 \\
\hline \begin{tabular}{|l|} 
Pendik \\
\end{tabular} & 79098 & 339378 & 162274 & 6.8 & 7.1 & 116.0 & 41.8 & 1648 \\
\hline Sancaktepe & 56727 & 316316 & 180071 & 2.3 & 3.4 & 119.5 & 38.7 & 2935 \\
\hline Sarıyer & 42513 & 1253259 & 748699 & 7.9 & 9.0 & 148.0 & 63.7 & 477 \\
\hline Şile & 12517 & 368533 & 158582 & 9.9 & 9.5 & 116.3 & 46.0 & 942 \\
\hline Silivri & 10427 & 291927 & 131257 & 9.0 & 9.1 & 127.4 & 49.0 & 670 \\
\hline Şişli & 57775 & 668161 & 507048 & 15.2 & 14.4 & 108.7 & 41.3 & 1206 \\
\hline Sultanbeyli & 5635 & 308437 & 151541 & 2.2 & 4.3 & 112.3 & 37.1 & 525 \\
\hline Sultangazi & 60156 & 284083 & 116920 & 5.2 & 6.2 & 116.9 & 43.1 & 1030 \\
\hline Tuzla & 67794 & 364549 & 191653 & 3.6 & 5.5 & 112.9 & 41.1 & 1116 \\
\hline Ümraniye & 69686 & 432552 & 227888 & 6.1 & 5.9 & 113.4 & 39.3 & 1801 \\
\hline Üsküdar & 35946 & 725594 & 671508 & 14.8 & 13.0 & 120.0 & 51.9 & 863 \\
\hline Zeytinburnu & 35904 & 515340 & 378192 & 14.2 & 10.1 & 113.9 & 44.4 & 471 \\
\hline Total & 2235245 & 510519 & 486533 & 8.4 & 10.6 & 118.9 & 46.1 & 25908 \\
\hline
\end{tabular}


Table 2. Robustness Checks

\begin{tabular}{|c|c|c|c|c|c|c|c|c|c|c|c|c|}
\hline Variables & Mode & el 1_1 & Mode & el 1_2 & Mode & el 1_3 & Mode & el 2_1 & Mode & el 2_2 & Mode & el 2_3 \\
\hline _cons & 11.39 & $* * *$ & 12.29 & $* * *$ & 11.36 & $* * *$ & 11.96 & $* * *$ & 12.83 & $* * *$ & 11.90 & $* * *$ \\
\hline age & .00 & $* * *$ & -0.01 & $* * *$ & - & - & \begin{tabular}{|l|}
-0.01 \\
\end{tabular} & $* * *$ & -0.01 & $* * *$ & - & - \\
\hline size & & $* * *$ & & - & & $* * *$ & & $* * *$ & - & - & 0.01 & $* * *$ \\
\hline Adalar & & $* * *$ & .00 & $* * *$ & & $* * *$ & 0.62 & $* * *$ & 0.69 & $* * *$ & 0.52 & $* * *$ \\
\hline Ataşehir & 91 & $* * *$ & 87 & $* * *$ & .90 & $* * *$ & -0.44 & $* * *$ & -0.42 & $* * *$ & -0.39 & $* * *$ \\
\hline Avcilar & & $* * *$ & & $* * *$ & & $* * *$ & & $* * *$ & 0.41 & $* * *$ & 0.42 & $* * *$ \\
\hline Bağcılar & .37 & $* * *$ & .31 & $* * *$ & .36 & $* * *$ & -0.24 & $* * *$ & -0.24 & $* * *$ & -0.23 & $* * *$ \\
\hline Bahçeliev & & $* * *$ & & $* * *$ & & $* * *$ & \begin{tabular}{|l|}
-0.02 \\
\end{tabular} & 0.001 & & $* * *$ & \begin{tabular}{|l|}
0.01 \\
\end{tabular} & 0.236 \\
\hline Bakırköy & & $* * *$ & & $* * *$ & & $* * *$ & & $* * *$ & 0.05 & $* * *$ & .05 & $* * *$ \\
\hline Başak & & $* * *$ & & $* * *$ & & $* * *$ & & $* * *$ & & $* * *$ & 86 & $* * *$ \\
\hline Bayra & & $* * *$ & & $* * *$ & & $* * *$ & & $* * *$ & & $* * *$ & 0.07 & $* * *$ \\
\hline Beşik & & $* * *$ & & $* * *$ & & $* * *$ & & $* * *$ & & $* * *$ & .10 & $* * *$ \\
\hline Beyk & & $* * *$ & & $* * *$ & & $* * *$ & & $* * *$ & & $* * *$ & 03 & $* * *$ \\
\hline Beylik & 26 & $* * *$ & 0.33 & $* * *$ & 25 & $* * *$ & 0.52 & $* * *$ & 0.72 & $* * *$ & 0.48 & $* * *$ \\
\hline Beyo & & $* * *$ & & $* * *$ & & $* * *$ & -0.39 & $* * *$ & -0.34 & $* * *$ & -0.35 & $* * *$ \\
\hline Büyü & 35 & $* * *$ & & $* * *$ & 33 & $* * *$ & 0.52 & $* * *$ & & $* * *$ & 46 & $* * *$ \\
\hline Çata & & $* * *$ & & $* * *$ & & $* * *$ & & $* * *$ & & $* * *$ & & $* * *$ \\
\hline Çekn & & $* * *$ & & $* * *$ & & $* * *$ & -0. & $* * *$ & -0. & $* * *$ & -0. & $* * *$ \\
\hline Esenl & & $* * *$ & -0.02 & 0.195 & & $* * *$ & & $* * *$ & & $* * *$ & -0. & $* * *$ \\
\hline Eseny & 0.01 & 0.288 & -0.14 & $* * *$ & -0.01 & 0.556 & -0.21 & $* * *$ & -0. & $* * *$ & -0.18 & $* * *$ \\
\hline Eyüр & & *** & & $* * *$ & & $* * *$ & -0 . & $* * *$ & -0 & $* * *$ & -0.46 & $* * *$ \\
\hline Fatih & & $* * *$ & 0.65 & $* * *$ & .71 & $* * *$ & 0.15 & $* * *$ & 0.17 & $* * *$ & 0.19 & $* * *$ \\
\hline Gazio & & $* * *$ & & $* * *$ & & $* * *$ & & $* * *$ & & $* * *$ & & $* * *$ \\
\hline Güng & & $* * *$ & & $* * *$ & & $* * *$ & -0 & $* * *$ & & $* * *$ & & $* * *$ \\
\hline Kadı & & $* * *$ & & $* * *$ & & $* * *$ & & $* * *$ & .02 & 0.001 & .00 & 0.839 \\
\hline Kağıt & & $* * *$ & & $* * *$ & & $* * *$ & & $* * *$ & & $* * *$ & & $* * *$ \\
\hline Kartal & & $* * *$ & & $* * *$ & 0.50 & $* * *$ & & $* * *$ & 0.00 & 0.881 & & $* * *$ \\
\hline Küçükç & & $* * *$ & & $* * *$ & & $* * *$ & & $* * *$ & .10 & *** & & $* * *$ \\
\hline Maltepe & .70 & $* * *$ & 0.68 & $* * *$ & 0.67 & $* * *$ & 0.03 & $* * *$ & 0.01 & 0.431 & 0.05 & $* * *$ \\
\hline \begin{tabular}{|l|} 
Pendik \\
\end{tabular} & & $* * *$ & & $* * *$ & & $* * *$ & & $* * *$ & 0.28 & *** & 0.26 & $* * *$ \\
\hline Sancakte & 0.32 & $* * *$ & 0.30 & $* * *$ & 0.33 & $* * *$ & -0.08 & $* * *$ & \begin{tabular}{|l|}
-0.09 \\
\end{tabular} & $* * *$ & \begin{tabular}{|l|}
-0.06 \\
\end{tabular} & $* * *$ \\
\hline Sarıyer & & $* * *$ & & $* * *$ & & $* * *$ & -0.26 & $* * *$ & -0.25 & $* * *$ & -0.22 & $* * *$ \\
\hline Şile & 0.36 & $* * *$ & 0.34 & $* * *$ & 0.34 & $* * *$ & 0.90 & $* * *$ & 1.15 & $* * *$ & 0.91 & $* * *$ \\
\hline Silivri & -0.11 & $* * *$ & -0.03 & 0.149 & -0.14 & $* * *$ & -0.31 & $* * *$ & -0.24 & $* * *$ & -0.31 & $* * *$ \\
\hline Şişli & & $* * *$ & & $* * *$ & & $* * *$ & 0.55 & $* * *$ & 0.50 & $* * *$ & 0.53 & $* * *$ \\
\hline Sultan & & $* * *$ & & $* * *$ & & $* * *$ & -0.23 & $* * *$ & -0.26 & $* * *$ & -0.18 & $* * *$ \\
\hline Sultangazi & & $* * *$ & -0.02 & 0.274 & 0.04 & $* * *$ & \begin{tabular}{|l|}
-0.28 \\
\end{tabular} & $* * *$ & -0.27 & $* * *$ & -0.25 & $* * *$ \\
\hline Tuzla & 0.35 & $* * *$ & 0.24 & $* * *$ & 0.35 & $* * *$ & \begin{tabular}{|l|}
-0.06 \\
\end{tabular} & $* * *$ & -0.09 & $* * *$ & -0.02 & $* * *$ \\
\hline Ümraniye & & $* * *$ & & $* * *$ & 0.61 & $* * *$ & 0.13 & $* * *$ & 0.10 & $* * *$ & 0.16 & $* * *$ \\
\hline Üsküdar & 0.92 & $* * *$ & 0.91 & $* * *$ & 0.87 & $* * *$ & 0.51 & $* * *$ & 0.54 & $* * *$ & 0.49 & $* * *$ \\
\hline Zeytinburnu & 0.68 & $* * *$ & 0.59 & $* * *$ & 0.64 & $* * *$ & 0.29 & $* * *$ & 0.28 & $* * *$ & 0.26 & $* *$ \\
\hline
\end{tabular}

$* * *: \mathrm{p}<0.001$

Source: own study. 
Table 3. Results of Model 1

\begin{tabular}{|c|c|c|c|c|}
\hline Dependent Variable: price_log & Coef. & Robust Std. Err. & $\mathbf{t}$ & $P>t$ \\
\hline cons & 11.3872 & 0.009 & 1306.85 & $* * *$ \\
\hline age & -0.0044 & 0.000 & -53.94 & $* * *$ \\
\hline size & 0.0071 & 0.000 & 358.13 & $* * *$ \\
\hline Beşiktaş & 1.5614 & 0.010 & 161.04 & $* * *$ \\
\hline Kadıköy & 1.4050 & 0.009 & 162.87 & $* * *$ \\
\hline Bakırköy & 1.3052 & 0.010 & 130.76 & $* * *$ \\
\hline Şişli & 1.0857 & 0.009 & 114.64 & $* * *$ \\
\hline Fatih & 0.8137 & 0.009 & 86.04 & $* * *$ \\
\hline Beyoğlu & 1.0763 & 0.012 & 91.92 & $* * *$ \\
\hline Üsküdar & 0.9217 & 0.010 & 96.3 & $* * *$ \\
\hline Sarıyer & 1.3638 & 0.010 & 140.98 & $* * *$ \\
\hline Eyüp & 0.6124 & 0.009 & 64.75 & $* * *$ \\
\hline Maltepe & 0.7018 & 0.009 & 81.55 & $* * *$ \\
\hline Kartal & 0.5239 & 0.009 & 59.74 & $* * *$ \\
\hline Küçükçekmece & 0.4345 & 0.009 & 48.33 & $* * *$ \\
\hline Bayrampaşa & 0.5029 & 0.011 & 45.58 & $* * *$ \\
\hline Büyükçekmece & 0.3499 & 0.009 & 38.68 & $* * *$ \\
\hline Bahçelievler & 0.4976 & 0.009 & 56.87 & $* * *$ \\
\hline Ataşehir & 0.9093 & 0.009 & 101.73 & $* * *$ \\
\hline Pendik & 0.2551 & 0.009 & 29.33 & $* * *$ \\
\hline Zeytinburnu & 0.6781 & 0.010 & 66.73 & $* * *$ \\
\hline Beylikdüzü & 0.2604 & 0.009 & 30.36 & $* * *$ \\
\hline Beykoz & 0.8744 & 0.014 & 64.74 & $* * *$ \\
\hline Tuzla & 0.3532 & 0.010 & 34.95 & $* * *$ \\
\hline Kağıthane & 0.5445 & 0.009 & 59.14 & $* * *$ \\
\hline Ümraniye & 0.6143 & 0.009 & 69.51 & $* * *$ \\
\hline Güngören & 0.5155 & 0.010 & 51.37 & $* * *$ \\
\hline Adalar & 1.0521 & 0.017 & 63.46 & $* * *$ \\
\hline Başakşehir & 0.5524 & 0.009 & 59.98 & $* * *$ \\
\hline Avcılar & 0.1932 & 0.009 & 22.15 & $* * *$ \\
\hline Bağcılar & 0.3719 & 0.010 & 38.53 & $* * *$ \\
\hline Esenyurt & -0.0112 & 0.009 & -1.31 & 0.19 \\
\hline Çatalca & 0.1285 & 0.027 & 4.84 & $* * *$ \\
\hline Çekmeköy & 0.3815 & 0.009 & 42.92 & $* * *$ \\
\hline Silivri & -0.1063 & 0.014 & -7.76 & $* * *$ \\
\hline Gaziosmanpaşa & 0.2709 & 0.009 & 30.02 & $* * *$ \\
\hline Sancaktepe & 0.3223 & 0.009 & 34.1 & $* * *$ \\
\hline Esenler & 0.1965 & 0.009 & 21.02 & $* * *$ \\
\hline Sultangazi & 0.0520 & 0.009 & 5.89 & $* * *$ \\
\hline Şile & 0.3643 & 0.019 & 18.87 & $* * *$ \\
\hline Sultanbeyli & 0.3675 & 0.021 & 17.32 & $* * *$ \\
\hline
\end{tabular}

Note: $\mathrm{R}^{2}=0.7049, \mathrm{p}=0.000$, base county: Arnavutköy, ${ }^{* * *}: \mathrm{p}=0.000$

Source: own elaboration based on data from REIDIN. 
Table 4. Results of Model 2

\begin{tabular}{|c|c|c|c|c|}
\hline Dependent Variable: price_log & Coef. & Std. Err. & $\mathbf{t}$ & $P>t$ \\
\hline _cons & 11.9570 & 0.003 & 3654.11 & $* * *$ \\
\hline age & -0.0055 & 0.000 & -181.09 & $* * *$ \\
\hline size & 0.0075 & 0.000 & 909.21 & $* * *$ \\
\hline Beşiktaş & 1.0937 & 0.004 & 275.60 & $* * *$ \\
\hline Kadıköy & 0.9113 & 0.003 & 278.05 & $* * *$ \\
\hline Şişli & 0.5543 & 0.004 & 146.29 & $* * *$ \\
\hline Bakırköy & 0.9018 & 0.004 & 232.35 & $* * *$ \\
\hline Maltepe & 0.2456 & 0.003 & 75.37 & $* * *$ \\
\hline Üsküdar & 0.5110 & 0.004 & 143.21 & $* * *$ \\
\hline Sarıyer & 0.9000 & 0.004 & 251.53 & $* * *$ \\
\hline Ataşehir & 0.4107 & 0.004 & 115.59 & $* * *$ \\
\hline Ümraniye & 0.1334 & 0.003 & 39.72 & $* * *$ \\
\hline Beyoğlu & 0.5249 & 0.005 & 106.55 & $* * *$ \\
\hline Fatih & 0.3147 & 0.004 & 87.44 & $* * *$ \\
\hline Avcilar & -0.2434 & 0.003 & -72.03 & $* * *$ \\
\hline Beylikdüzü & -0.3854 & 0.003 & -116.15 & $* * *$ \\
\hline Tuzla & -0.0587 & 0.003 & -16.83 & $* * *$ \\
\hline Çekmeköy & -0.1019 & 0.003 & -30.11 & $* * *$ \\
\hline Başakşehir & 0.0462 & 0.004 & 12.82 & $* * *$ \\
\hline Pendik & -0.0835 & 0.003 & -25.01 & $* * *$ \\
\hline Kartal & 0.0956 & 0.003 & 28.76 & $* * *$ \\
\hline Küçükçekmece & 0.0345 & 0.003 & 10.14 & $* * *$ \\
\hline Bayrampaşa & 0.0860 & 0.004 & 21.75 & $* * *$ \\
\hline Eyüp & 0.1525 & 0.003 & 43.91 & $* * *$ \\
\hline Silivri & -0.3142 & 0.004 & -79.58 & $* * *$ \\
\hline Beykoz & 0.5157 & 0.006 & 88.71 & $* * *$ \\
\hline Esenler & -0.2080 & 0.004 & -58.45 & $* * *$ \\
\hline Kağıthane & 0.1163 & 0.003 & 34.38 & $* * *$ \\
\hline Bahçelievler & 0.0466 & 0.003 & 13.83 & $* * *$ \\
\hline Güngören & 0.0598 & 0.004 & 15.86 & $* * *$ \\
\hline Gaziosmanpaşa & -0.0510 & 0.004 & -14.56 & $* * *$ \\
\hline Büyükçekmece & -0.0518 & 0.004 & -14.76 & $* * *$ \\
\hline Zeytinburnu & 0.2852 & 0.004 & 73.45 & $* * *$ \\
\hline Sultanbeyli & -0.2272 & 0.004 & -52.61 & $* * *$ \\
\hline Esenyurt & -0.5058 & 0.003 & -153.63 & $* * *$ \\
\hline Arnavutköy & -0.4350 & 0.004 & -122.05 & $* * *$ \\
\hline Çatalca & -0.3058 & 0.007 & -47.01 & $* * *$ \\
\hline Bağcılar & -0.0158 & 0.004 & -4.41 & $* * *$ \\
\hline Sancaktepe & -0.2639 & 0.003 & -76.30 & $* * *$ \\
\hline Sultangazi & -0.2755 & 0.003 & -82.14 & $* * *$ \\
\hline Adalar & 0.6154 & 0.006 & 99.27 & $* * *$ \\
\hline
\end{tabular}

Note: $R^{2}=0.7348, p=0.000$, base county: Şile, ${ }^{* * *}: p=0.000$

Source: own elaborations based on data from REIDIN. 
Our estimations yielded heteroscedastic error terms; Model 1 more so, which is a common problem with hedonic models. We estimated the model with robust standard errors as the literature suggests (Hill, 2011). The distribution of errors improved much and we report these estimation results as final in Table 3 and Table 4. Variance inflation factor in both our estimations showed no sign of multicollinearity. Omitted variable bias is present in both our estimations, but it is not fatal for our analysis, since we use the rankings of coefficient, which is not affected by the bias.

In Table 3, we present the estimation results for Model 1, fitted to sales ads data covering 390530 observations between January 1, 2015 and December 31, 2016. The model is fit as the $p$-value is 0.000 and the adjusted $R^{2}$ is 0.7049 , which is fairly high for a hedonic model, particularly when considering the high number of levels in the county variable. The slope coefficients of age and size are estimated to be -0.0044 and 0.0071 , respectively. As for the county variable, we found all but one county's coefficient to be significant at 0.001 level. The coefficients are listed in respect to their ranking from the "Life Quality Index" (LQI; Şeker, 2015).

Table 4 displays the findings from our second model, estimated using a dataset consisting of 1844715 observations from January 1, 2017 to July 15, 2018. The statistics for the fitness of the model are obtained as $p$-value $=0.000$ and the adjusted $R^{2}=0.7348$. The slope coefficients of age and size are estimated to be -0.0055 and 0.0075 , respectively. As for the county variable, we found all counties' coefficients to be significant at 0.001 level. The coefficients are listed in respect to their ranking from the "Human Development Index 2017" (HDI; Şeker, Bakış, \& Dizeci, 2018).

\section{Correlations}

Table 5 displays the correlations between counties' price rankings obtained from models and index rankings with the use of Spearman's rank order correlation method. The results indicate strong - and positive correlation between rankings of price and index that belong the same time period, $77 \%$ and $57 \%$ respectively. The coefficients of first model are more in line with the LQI rankings than that of the second model with the HDI rankings. The results of this analysis support $\mathrm{H}_{1}$.

Table 5. Correlations

\begin{tabular}{|c|c|}
\hline LQI - Model 1 & HDI - Model 2 \\
\hline $0.77^{*}$ & $0.57^{*}$ \\
\hline
\end{tabular}

*: $\mathrm{p}<0.05$

Note: LQI - Life Quality Index; HDI - Human Development Index.

Source: own study.

\section{Discussion}

In terms of direction and magnitude, the coefficients of age and size in both estimations are logically correct; and they are also parallel and in reasonable proportion to the previous findings in literature (Berry \& Bednarz, 1975; Can, 1992; Li \& Brown, 1980; Ozus et al., 2007; Song \& Knaap, 2004). Considering the heterogeneous nature of the real estate market, our main focus here is county, as the development level of a county implies an impact on its price according to the hedonic approach. Being a categorical variable, each county's coefficient 
represents the percentage of marginal change in logarithm of prices. We ranked the coefficients of different levels of the county variable from the largest to the smallest; and obtained a price ranking for each model. We present ranks of price from the first model and the LQI in Figure 1, while the price from the second model and the HDI in Figure 2. The geographical locations and administrative borders of counties are presented in Figure 3.

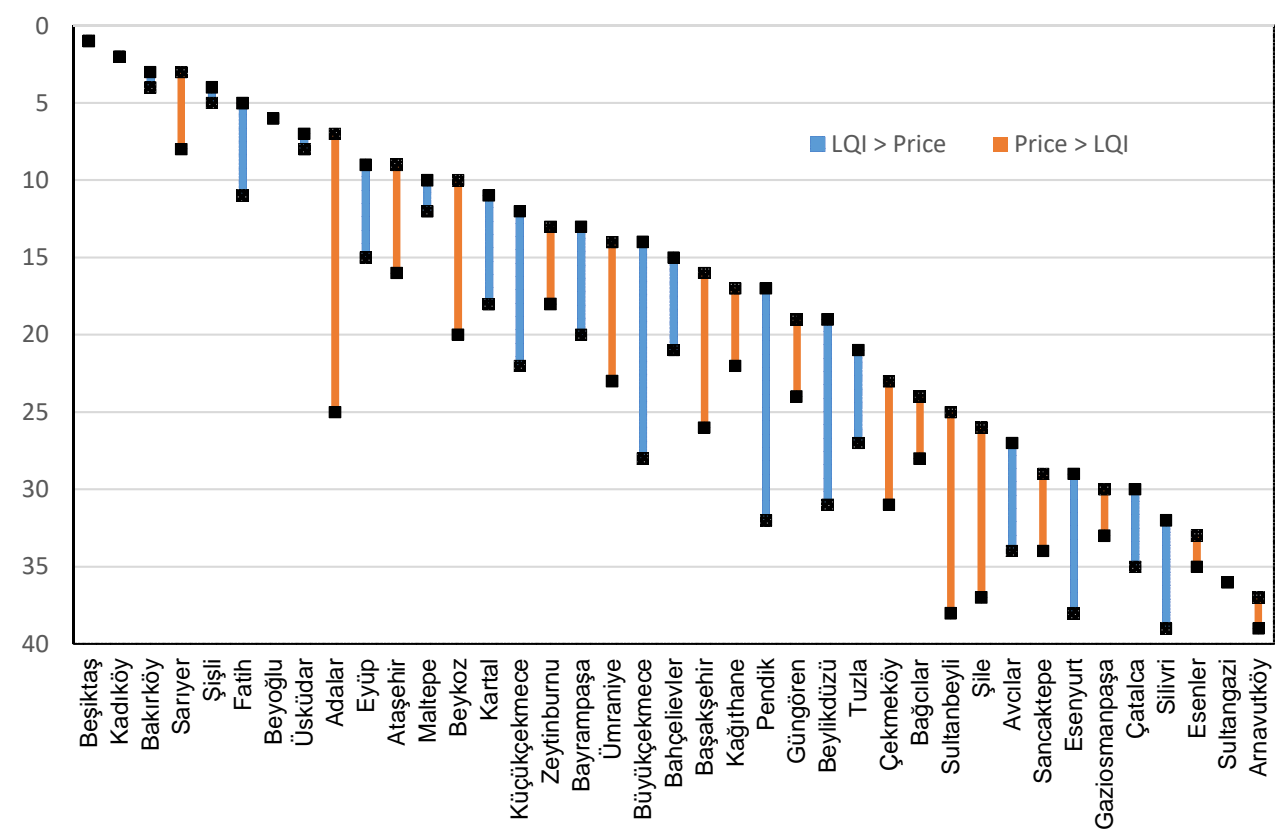

Figure 1. Counties' ranking of coefficients from first model and Life Quality Index Source: own elaboration.

The county with the highest apartment prices in both models is found to be Beşiktaş. This is coherent with that county's ranking in indices, as Beşiktaş tops both the LQI and the HDI.

Our first focus is older counties in the inner parts of the city. On 12 occasions across both models, mean deviation between the price and index rankings of Beşiktaş, Kadıköy, Bakırköy, Üsküdar, Şişli, and Fatih is found to be only 1.25. The correlation between index and price rankings of these counties emerged to be 0.910 and 0.98 in Model 1 and Model 2, respectively. These findings support $\mathrm{H}_{2}$.

Among the counties whose index ranking is higher than the price ranking are Beylikdüzü, Büyükçekmece, Pendik, and Küçükçekmece in the first model; and Beylikdüzü, Çekmeköy, Pendik, Silivri, and Tuzla in the second model. Said countries feature qualities of suburbanised areas; with limited public transportation to the city centre, low average age of houses, a high number of new constructions, and proper access to nearby social amenities and services. From the data presented in Table1, new building permits from 2015 to 2018 in the said counties from the first model make up 6853 combined; the same number for the second model is 6623 . These numbers are both larger than a quarter of all permits in Istanbul given in that period. These results show that counties undergoing the suburbanisation process rank higher in socioeconomic development than price; therefore, $\mathrm{H}_{3}$ is supported. 


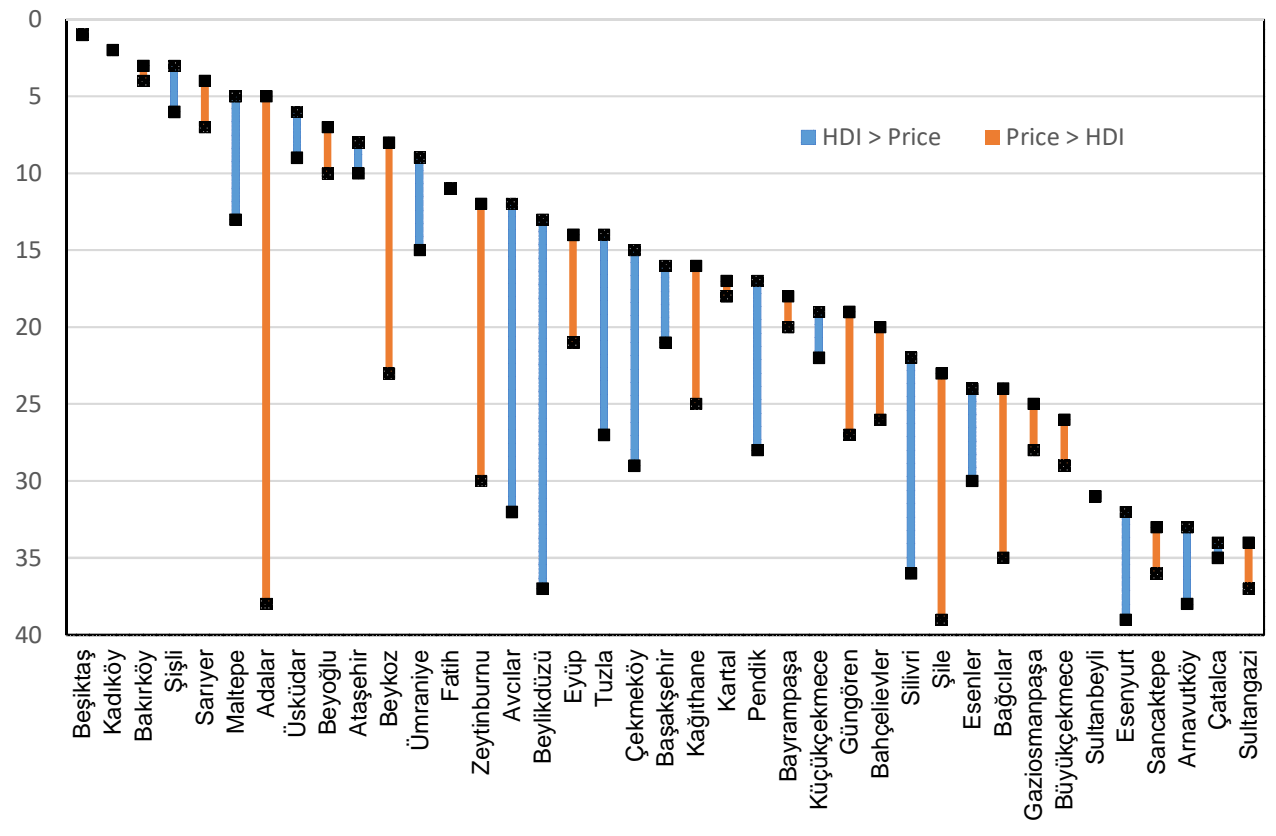

Figure 2. Counties' ranking of coefficients from second model and Human Development Index Source: own elaboration.

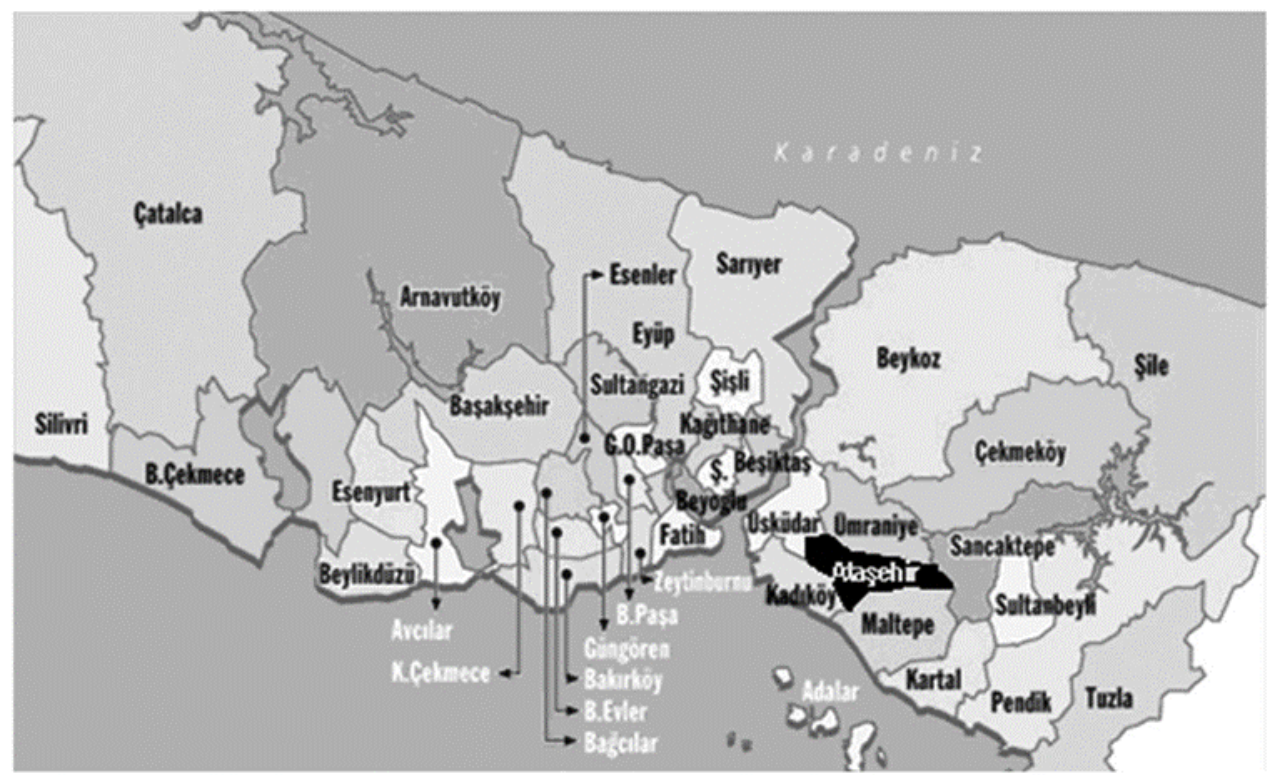

Figure 3. Map of Counties of Istanbul

Source: Istanbul Metropolitan Municipality. 
Among the factors that account for housing prices to be lower in suburbanised counties in comparison to their social development levels, two in particular appear to be in effect here. The first is that all of those counties are far from the city centre and closer to the peripheries. This potential reason proves true even when high social development exists, because the evidence from metropolitan areas show that the very distance of a suburb from the centre drives a need to establish a socially developed environment within (Ciraci \& Kundak, 2000; Eraydın, 2008; Keyder, 2005; Kolluoglu \& Bartu Candan, 2008; Mieszkowski \& Smith, 1991; Ottensmann, Payton, \& Man, 2008). The second factor is the unparalleled rapid development of construction projects in said counties (Eraydın, 2008). One can expect this situation to translate into higher housing prices (Karaman \& Islam, 2012; Kuyucu \& Ünsal, 2010; White, 1975). However, the new construction projects have led to a sufficient influx of housing supply to keep prices in check by meeting the demand adequately on average for long periods (Ozsoy et al., 2003).

The counties that have gentrified areas indeed show to have higher rankings in price than respective index rankings, thus supporting $\mathrm{H}_{4}$. Başakşehir, Sultanbeyli, and Ümraniye in the first model and Bağcılar, Kağıthane, and Zeytinburnu in the second model fall into this group. Except for Başakşehir, whose urban transformation consists mostly of new housing projects, these counties have been homes to squatters. Among them, Zeytinburnu, Bağcılar, Kağıthane, and Ümraniye are in the proximity of the inner city on both sides of Bosphorus, which attracted migrant settlements and squatters for years. Bağcılar, Kağıthane, and Zeytinburnu have a common characteristic that drives the sales price of apartments higher: they are located in the immediate hinterland of the central parts of Istanbul. Their social structures once consisted of squatters and slums built by immigrants (Ozcevik et al., 2007). They were occupied by manufacturing facilities and their workers, as Bağcılar was the county with mostly workers dwellings (Ocakçı, 2000), but then they turned into centres of sprawl in the 2000's (Akdogan, 2009). Later, it became a site for urban regeneration programs since 2011, thanks to the aforementioned legislation that promise urban aesthetic and durability against the threat of an earthquake (Bodur \& Dülgeroğlu Yüksel, 2017; Karaman, 2009; Ozcevik et al., 2008; Yapıcı \& Ileri, 2019). The reason why Başakşehir is among these counties is regarding its special case of transformation. Started as a satellite city with very limited public transportation and many new constructions every year, Başakşehir used to be a suburbanised county. With recent introductions of the metro line and multiple bus lines covering the nearby suburban areas, Başakşehir transformed into a centre on its own. Consequently, Istanbul's evolution into a multi-centred city can be attributed to TOKI's actions, which display similarities to actions of a for-profit institution (Güney, Keil, \& Üçoğlu, 2019).

Despite the policymakers' argument that the urban redevelopment in Istanbul is done for risk mitigation, many parties from academia and NGOs are suspicious of an underlying motive of interest-seeking through gentrification (Ergun, 2004; Islam, 2010; Karaman \& Islam, 2012; Lovering \& Türkmen, 2011; OECD, 2018; Pinarcioğlu \& Isik, 2008; Yapıcı \& lleri, 2019; Yetiskul, Kayasü, \& Ozdemir, 2016). This concern is mostly backed by our findings, especially in the case of counties with gentrified areas. These counties used to accommodate the poor and the middle class; they used to have low social development and bad infrastructure (Ozus, Turk, \& Dokmeci, 2011). Thanks to easy access to main highways and with the 
addition of new units, the housing prices are now much higher than before. As a consequence, their demographic is replaced by high-income households (Öktem, 2011). However, since the land is already almost fully occupied, a rapid transformation occurred in the housing sector, in form of one house replacing the old one's spot, which does not necessarily accelerate the improvement of infrastructure or social amenities in the vicinity. Hence, a higher HDI ranking in said counties is expected to follow the increase in housing prices.

\section{CONCLUSIONS}

In our study, we analysed the housing prices in Istanbul at county level by hedonic modelling; then, we extrapolated the results by juxtaposing them onto the LQI (Şeker, 2015) and the HDI (Şeker, Bakış, \& Dizeci, 2018). We pursued a standardisation to reduce the complexity of the problem at hand by using data from apartment units only. We ranked the coefficients of the counties and compared them with their corresponding index rankings. As an effect, all four hypotheses are supported by the findings.

According to our results, the socioeconomic development level of the area in which a housing unit is located is highly correlated with its price. The socioeconomic development level of a house's county appears to have a positive relationship with the price. The locational attributes as a whole provided a practical interpretation of price that is applicable to any house available on market. The housing units in older counties are the group with prices most in line with the socioeconomic development levels. Counties undergoing the suburbanisation process rank lower in price than in human development. Counties under the gentrification process display the opposite outcome, as they rank higher in price than in human development.

In light of the findings and existing literature, urban transformation methods and changing levels of human development display different relationships with housing prices. It is especially significant when a metropolitan city such as Istanbul has been undergoing every aspect of urban transformation for over a decade. This relationship might be driving the urban transformation process in Istanbul, since it is likely to generate revenue through cultivating the potential of an existing resource: land. Gentrification and suburbanisation at a very aggressive rate in Istanbul, or in any metropolitan area, would result in pushing lower income inhabitants to the outer parts and raising a new demographic almost in every part of the city. This strategy is likely to diminish the characteristics of the city, which hurts not only the sociodemographic landscape but also the economic one, as the two are shown to be linked by an elated body of research, including this study.

Our study proposed a comprehensive approach to analysing Istanbul's housing prices, combining results from quantitative methods and a case study. Our analysis also involved a retrospective and political analysis of the city's counties and an assessment of social development levels with a focus on the counties' characteristics. The study's most important limitation is the use of few variables. Our model suffered from omitted variable bias; therefore, future research can take the route of adding more structural variables to the model so as to better analyse the housing market in Istanbul. There is room for improvement in this line of research that can be achieved by ranking smaller areas such as neighbourhoods to the locational effects as a whole investigated with higher precision. Extending this study to different types of housing is expected to provide a better insight from the comparison of results. 


\section{REFERENCES}

Akdogan, G. (2009). Dealing with rapid development: Creation of the informal urban economy and gecekondu housing in Istanbul. lowa State University.

Atkinson, R., \& Bridge, G. (2005). Gentrification in a Global Context: The New Urban Colonialism. New York: Routledge. https://doi.org/10.4324/9780203392089

Berry, B.J.L., \& Bednarz, R.S. (1975). A Hedonic Model of Prices and Assessments for Single-Family Homes: Does the Assessor Follow the Market or the Market Follow the Assessor?. Land Economics, 51(1), 21-40.

Billingham, C.M. (2015). The Broadening Conception of Gentrification: Recent Developments and Avenues for Future Inquiry in the Sociological Study of Urban Change. Michigan Sociological Review, 29(Fall 2015), 75-102.

Bodur, A., \& Dülgeroğlu Yüksel, Y. (2017). Assessing change in quality of life following rehousing from slum settlements to social housing. A/Z ITU Journal of the Faculty of Architecture, 14(3), 53-65. https://doi.org/10.5505/itujfa.2018.36002

Bradbury, K., Engle, R., Irvine, O., \& Rothenberg, J. (1977). Simultaneous estimation of the supply and demand for housing location in a multizoned metropolitan area. In G.K. Ingram (Ed.), Residential Location and Urban Housing Markets (pp. 51-92). National Bureau of Economic Research.

Can, A. (1992). Specification and estimation of hedonic housing price models. Regional Science and Urban Economics, 22(3), 453-474. https://doi.org/10.1016/0166-0462(92)90039-4

Ciraci, H., \& Kundak, S. (2000). Changing Urban Pattern of Istanbul: from Monocentric To Polycentric Structure. 40th Congress of the European Regional Science Association. Barcelona, Spain.

Clarke, K.A. (2005). The phantom menace: Omitted variable bias in econometric research. Conflict Management and Peace Science, 22(4), 341-352. https://doi.org/10.1080/07388940500339183

de Haan, J., \& Diewert, E. (2013). Hedonic Regression Methods. In Handbook on Residential Property Price Indices (pp. 49-64). Luxembourg: Eurostat.

Dokmeci, V., Berkoz, L., Levent, H., Yurekli, H., \& Cagdas, G. (1996). Residential preferences in Istanbul. Habitat International, 20(2), 241-251.

Efe, R., Bizzarri, C., Cürebal, I., \& Nyussupova, G. (2015). Environment and Ecology at the Beginning of 21 st Century. In R. Efe, C. Bizzarri, I. Cürebal, \& G. Nyussupova, (Eds.). Sofia: St. Kliment Ohridski University Press.

Eraydın, A. (2008). The Conditional Nature of Relations Between Competitiveness, Social Cohesion and Spatial Inequalities: The Evidence from Istanbul. In P. Ache, H.T. Andersen, T. Maloutas, M. Raco, \& T. Taşan-Kok (Eds.), Cities between Competitiveness and Cohesion (pp. 99-115). Springer. https://doi.org/10.1007/978-1-4020-8241-2

Ergun, N. (2004). Gentrification in Istanbul. Cities, 21(5), 391-405. https://doi.org/10.1016/ j.cities.2004.07.004

Fletcher, M., Gallimore, P., \& Mangan, J. (2000). Heteroscedasticity in hedonic house price models. Journal of Property Research, 17(2), 93-108. https://doi.org/10.1080/095999100367930

Frenkel, A., Bendit, E., \& Kaplan, S. (2013). The linkage between the lifestyle of knowledgeworkers and their intra-metropolitan residential choice: A clustering approach based on self-organizing maps. Computers, Environment and Urban Systems, 39, 151-161. https://doi.org/10.1016/j.compenvurbsys.2012.09.001 
Głuszak, M. (2018). Externalities and house prices: A stated preferences approach. Entrepreneurial Business and Economics Review, 6(4), 181-196. https://doi.org/10.15678/EBER.2018.060410

Goodman, A.C. (1978). Hedonic Prices, Price Indices and Housing Markets. Journal of Urban Economics, 5, 471.

Goodman, A.C., \& Thibodeau, T.G. (2003). Housing market segmentation and hedonic prediction accuracy. Journal of Housing Economics, 12(3), 181-201. https://doi.org/10.1016/S10511377(03)00031-7

Guerrieri, V., Hartley, D., \& Hurst, E. (2013). Endogenous gentrification and housing price dynamics. Journal of Public Economics, 100, 45-60. https://doi.org/10.1016/j.jpubeco.2013.02.001

Güler, E.Z. (2013). Urban renewal in working class areas in Istanbul De-industrialization and urban renewal in Beykoz - Paşabahçe Istanbul. In RC21 Resourceful Cities (pp. 8-10). Berlin, Germany.

Gülersoy, N.Z., \& Güler, E. (2011). Conceptual challenges on urban transformation. ITU A/Z, 8(1), 10-24.

Güney, K.M., Keil, R., \& Üçoğlu, M. (2019). Massive Suburbanization: (Re)Building the Global Periphery. Toronto: University of Toronto Press.

Heyman, A.V., \& Sommervoll, D.E. (2019). House prices and relative location. Cities, 95(April). https://doi.org/10.1016/j.cities.2019.06.004

Hill, R. (2011). Hedonic price indexes for housing. OECD Statistics Working Papers, (1), 3-61. https://doi.org/10.1787/5kghzxpt6g6f-en

Hülagü, T., Kızılkaya, E., Özbekler, A.G., \& Tunar, P. (2016). A Hedonic House Price Index for Turkey.

Islam, T. (2010). Current Urban Discourse: Urban Transformation and Gentrification in Istanbul. Architectural Design, 80(1), 58-63.

Kangallı Uyar, S.G. (2015). Hedonik fiyat teorisi çerçevesinde istanbul konut piyasası fiyat dinamiklerinin parametrik ve parametrik olmayan mekânsal modeller ile karşılaştırmalı analizi (Doctoral dissertation). Pamukkale University, Turkey.

Karaman, O. (2009). Urban Pulse - (RE)Making Space for Globalization in Istanbul. Urban Geography, 29(6), 518-525. https://doi.org/10.2747/0272-3638.29.6.518

Karaman, O., \& Islam, T. (2012). On the Dual Nature of intra-urban borders: The case of a Romani neighborhood in Istanbul. Cities, 29(4), 234-243. https://doi.org/10.1016/j.cities.2011.09.007

Kaya, A. (2012). Türkiye'de Konut Fiyatlarını Etkileyen Faktörlerin Hedonik Fiyat Modeli ile Belirlenmesi. Specialist Dissertation submitted to TCMB Statistics Department.

Keskin, B. (2008). Hedonic analysis of price in the istanbul housing market. International Journal of Strategic Property Management, 12(2), 125-138. https://doi.org/10.3846/1648715X.2008.12.125-138

Keyder, Ç. (2005). Globalization and Social Exclusion in Istanbul. International Journal of Urban and Regional Research, 29(1), 124-134.

Kisar Koramaz, E., Koramaz, T.K., \& Özer, Ö. (2018). Urban transformation through property-led regeneration: A case of building renewals in Istanbul. A/Z ITU Journal of the Faculty of Architecture, 15(2), 183-196. https://doi.org/10.5505/itujfa.2018.95815

Kolluoglu, B., \& Bartu Candan, A. (2008). Emerging Spaces of Neoliberalism: A Gated Town and a Public Housing Project in Istanbul. New Perspectives on Turkey, 39(1), 5-46. https://doi.org/10.1017/S0896634600005057

Kuyucu, T., \& Ünsal, Ö. (2010). “Urban transformation” as state-led property transfer: An analysis of two cases of urban renewal in Istanbul. Urban Studies, 47(7), 1479-1499. https://doi.org/10.1177/0042098009353629 
Li, M.M., \& Brown, J.H. (1980). Micro-Neighborhood Externalities and Hedonic Housing Prices. Land Economics, 56(2), 125-141.

Lipscomb, C. (2006). An Alternative Spatial Hedonic Estimation Approach. Journal of Housing Research, 15(2), 143-160.

Lovering, J., \& Türkmen, H. (2011). Bulldozer neo-liberalism in Istanbul: The state-led construction of property markets, and the displacement of the urban poor. International Planning Studies, 16(1), 73-96. https://doi.org/10.1080/13563475.2011.552477

Martin, I.W., \& Beck, K. (2018). Gentrification, property tax limitation, and displacement. Urban Affairs Review, 54(1), 33-73. https://doi.org/10.1177/1078087416666959

Michalos, A.C. (2014). Encyclopedia of Quality of Life and Well-Being Research. https://doi.org/10.1007/978-94-007-0753-5

Mieszkowski, P., \& Smith, B. (1991). Analyzing urban decentralization. The case of Houston. Regional Science and Urban Economics, 21(2), 183-199. https://doi.org/10.1016/0166-0462(91)90033-J

Montgomery, M.R. (2008). The urban transformation of the developing world. Science, 319(5864), 761-764. https://doi.org/10.1126/science.1153012

NYU Furman Center. (2015). State of New York City's Housing and Neighborhoods in 2015. New York. https://doi.org/10.2139/ssrn.2610700

Ocakçı, M. (2000). Commuting Pattern of Industrial Laborers in the Istanbul Metropolitan Area. Cities, 17(1), 55-61.

OECD. (2018). OECD Economic Surveys: Turkey Overview.

Öktem, B. (2011). The role of global city discourses in the development and transformation of the Buyukdere-Maslak axis into the international business district of Istanbul. International Planning Studies, 16(1), 27-42. https://doi.org/10.1080/13563475.2011.552498

Ottensmann, J. R., Payton, S., \& Man, J. (2008). Urban Location and Housing Prices within a Hedonic Model. Journal of Regional Analysis and Policy, 38(1), 19-35.

Ozcevik, O., Turk, S.S., Beygo, C., Akcakaya, I., \& Sen, K. (2007). Community Development for Sustainable Urban Regeneration: Reflections of Zeytinburnu Ottoman Neighbourhood Case. ENHR International Conference on Sustainable Urban Areas (pp. 1-19). Rotterdam, Netherlands.

Ozcevik, O., Turk, S., Tas, E., Yaman, H., \& Beygo, C. (2008). Flagship regeneration project as a tool for post-disaster recovery planning: the Zeytinburnu case. Disasters, 33(2), 180-202. https://doi.org/10.1111/j.1467-7717.2008.01069.x

Özdemir Sarı, Ö.B., Özdemir, S.S., \& Uzun, N. (Eds.). (2019). Urban and Regional Planning in Turkey. Cham: Springer International Publishing. https://doi.org/10.1007/978-3-030-05773-2

Ozden, P. (2012). Culture-led regeneration projects in post-industrial areas: the Istanbul experience. In Transactions on Ecology and The Environment (pp. 823-834). https://doi.org/10.2495/SC120692

Ozsoy, A., Altas, N.E., Ok, V., \& Pulat, G. (2003). Quality assessment model for housing. Habitat International, 20(2), 163-173. https://doi.org/10.1016/0197-3975(95)00045-3

Ozus, E., Dokmeci, V., Kiroglu, G., \& Egdemir, G. (2007). Spatial analysis of residential prices in Istanbul. European Planning Studies, 15(5), 707-721. https://doi.org/10.1080/09654310701214085

Ozus, E., Turk, S.S., \& Dokmeci, V. (2011). Urban restructuring of Istanbul. European Planning Studies, 19(2), 331-356. https://doi.org/10.1080/09654313.2010.515826

Pinarcioğlu, M., \& Isik, O. (2008). Not only helpless but also hopeless: Changing dynamics of urban poverty in Turkey, the case of Sultanbeyli, Istanbul. European Planning Studies, 16(10), 13531370.

https://doi.org/10.1080/09654310802420060 
Salkind, N. (2010). Encyclopedia of Research Design. Dictionary of Statistics \& Methodology. Thousand Oaks: SAGE Publications. https://doi.org/10.4135/9781412961288

Şeker, M. (2015). Quality of Life Index: A Case Study of İstanbul. Ekonometri ve Istatistik, (23), 1-15. Şeker, M., Bakış, Ç., \& Dizeci, B. (2018). Insani Gelişme Endeksi - Illçeler 2017. İstanbul: inGEV Yayınları.

Song, Y., \& Knaap, G.J. (2004). Measuring the effects of mixed land uses on housing values. Regional Science and Urban Economics, 34(6), 663-680. https://doi.org/10.1016/j.regsciurbeco.2004.02.003

Steinmetz-Wood, M., Wasfi, R., Parker, G., Bornstein, L., Caron, J., \& Kestens, Y. (2017). Is gentrification all bad? Positive association between gentrification and individual's perceived neighborhood collective efficacy in Montreal, Canada. International Journal of Health Geographics, 16(24), 1-8. https://doi.org/10.1186/s12942-017-0096-6

Tang, Z. (2006). The Urban Housing Market in a Transitional Economy: Shanghai as a Case Study (Doctoral dissertation). Indiana University, USA.

The World Bank. (2015). Rise of the Anatolian Tigers: Turkey Urbanization Review.

Turkmen, H. (2014). Urban renewal projects and dynamics of contention in Istanbul: The cases of Fener-Balat-Ayvansaray and Suleymaniye. Cardiff University.

Wacquant, L. (2008). Relocating gentrification: The working class, science and the state in recent urban research. International Journal of Urban and Regional Research, 32(1), 198-205. https://doi.org/10.1111/j.1468-2427.2008.00774.x

White, M.J. (1975). The Effect of Zoning on the Size of Metropolitan Areas. Journal of Urban Economics, 2(4), 279-290.

Xiao, Y. (2017). Urban Morphology and Housing Market. Shanghai: Springer. https://doi.org/10.1007/978-981-10-2762-8

Yapıcı, M., \& lleri, E. (2019). Urban Transformation in Istanbul. In E. Özyürek, G. Özpınar, \& E. Altındiş (Eds.), Authoritarianism and Resistance in Turkey. Springer.

Yetiskul, E., Kayasü, S., \& Ozdemir, S. Y. (2016). Local responses to urban redevelopment projects: The case of Beyoğlu, Istanbul. Habitat International, 51, 159-167. https://doi.org/10.1016/j.habitatint.2015.10.019

Yılmaz Bakır, N. (2019). Project-Based Urban Renewal and Transformation of Urban Landscape in Turkey. In Landscape Reclamation - Rising From What's Left [Working Title] (pp. 1-22). InTech Open.

Zambon, I., \& Salvati, L. (2019). Metropolitan growth, urban cycles and housing in a Mediterranean country, 1910s-2010s. Cities, 95(July), 102412. https://doi.org/10.1016/j.cities.2019.102412 


\section{Authors}

The contribution share of authors is equal and amounted to $50 \%$ each of them.

\section{Meltem Ucal}

Professor at the Department of Economics, Kadir Has University. Her research interests include housing prices, energy economics, poverty, foreign direct investments, labour force participation, and wage gap.

Correspondence to: Prof. Dr. Meltem Ucal, Kadir Has University, Faculty of Economics, Administrative and Social Sciences, Kadir Has Cad., 34083, Turkey, e-mail: msengun@khas.edu.tr or meltem.sengun@gmail.com

ORCID (1) http://orcid.org/0000-0003-3707-1948

\section{Uğur Kaplan}

PhD student at the Graduate School of Social Sciences, Gazi University. His research interests include decision modelling and consumer behaviour.

Correspondence to: Uğur Kaplan, Gazi University, Graduate School of Social Sciences, Ankara, Turkey, e-mail: ukivernest@hotmail.com

ORCID ㄴ) http://orcid.org/0000-0003-3448-6435

\section{Acknowledgements and Financial Disclosure}

The article came into being within the project no. 2017-BAP-10 entitled "Macroeconomic Factors Influencing Real Estate Markets on Several Counts in Istanbul and Modelling" financed by Kadir Has University, conducted by Meltem Ucal in 2017-2018.

The authors would like to thank the anonymous referees for their useful comments, which allowed for increasing the value of this article.

The authors would like to express their gratitude to Simge Günay for her valuable assistance in the research study.

\section{Copyright and License}

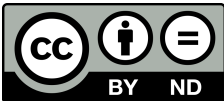

This article is published under the terms of the Creative Commons

Attribution - NoDerivs (CC BY-ND 4.0) License

http://creativecommons.org/licenses/by-nd/4.0/

Published by the Centre for Strategic and International Entrepreneurship - Krakow, Poland 
